\title{
STATISTICAL OBSERVATION OF PERSEPTIVE DEAFNESS
}

One year's observation at the Department of Otorhinolaryngology of Osaka University Hospital

\section{By}

T. HANADA. Y. WATANABE. K. FUJII, A. ARITA, K. KITA AND K. ICHIYOSHI

From the Department of Oto-Rhino-Laryngology, Faculty of Medicine, Univ. of Osaka (Director: Prof. T. Hasegawa)

Among all out-patients seen at the Department of Otorhinolaryngology of Osaka University Hospital, 1034 cases of probable perceptive deafness were selected for our statistical observation.

This disorder was found to be considerably wide in its age distribution, though its highest incidence was seen among the twentiesi. Males were more affected than women.

In the majorty of cases, the exact cause was unknown. In these cases, the type of hearing loss was either slowly-descending toward high-pitch sound, horizontal or steep-falling on high-pitch sound.

Bilateral hearing loss of perceptive type was frequently encountered in Ménière's disease and sudden-deafness.

Acoustic trauma was predominantly common among males.

$$
\begin{aligned}
& \text { 感音系難 聴 の統 計的 観 察 } \\
& \text { 大阪大学医学部耳鼻咽娭科教室（主任：長谷川高敏教授） }
\end{aligned}
$$

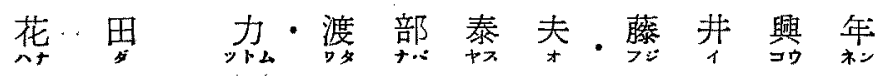

$$
\begin{aligned}
& \text { 在思、淳子子、喜多恭子市、市声和 }
\end{aligned}
$$

\section{1. 粕 言}

Audiology のめざしい進歩にも拘らず，感音系難 聴の臨床，とくにその統計的観察はその報告，極めて少 く，本邦に和いてて昭和 25 年，東大より報告されたの が最も新しい統計資料子思わ机る。我々は，昭和 33 年 度，阪大病院耳勫科外来患者 11248 名の中，聴力検査拉 よび，嫴膜，耳管等の所見より感音系難聴々考えられた 1034 名を対象とし，その統計的観察を試みたので報告 する.

\section{2. 統計的観察}

1. 性および年令

男女比は 1.8:1 の比で男性に多い(第1表). 年令胢 では，20才代㶴いか，60手代迄広い、分在を示して いる. 東大の分類に比較し，0〜9才代に抋いて少いの は整喛が少いためであり，20〜29 寸代で最も多いのは
従来の統計と同じであるが，その年命別の分布は広範囲 に及んでいる(第1図).

\begin{tabular}{|c|c|c|c|c|}
\hline & $\hat{\delta}$ & q & 棓 & $(\%)$ \\
\hline $0 \sim 97$ & 49 & 30 & 79 & 7.6 \\
\hline $10 \sim 19$ & 88 & 50 & 138 & 13.3 \\
\hline $20 \sim 29$ & 139 & 94 & 233 & 22.5 \\
\hline $30 \sim 39$ & 113 & 54 & 167 & 16.2 \\
\hline $40 \sim 49$ & 114 & 45 & 159 & 15.4 \\
\hline $50 \sim 59$ & 88 & 49 & 137 & 13.3 \\
\hline $60 \sim 69$ & 61 & 34 & 95 & 9.2 \\
\hline $70 \sim 79$ & 14 & 10 & 24 & 2.3 \\
\hline $80 \sim$ & 1 & 1 & 2 & 0.2 \\
\hline 䧸 & 667 & 367 & 1034 & 100.0 \\
\hline
\end{tabular}

第 1 表 感音系難罣例（年令別，性別） 
第 1 図 感音系難聴 1034 名 年令別分類

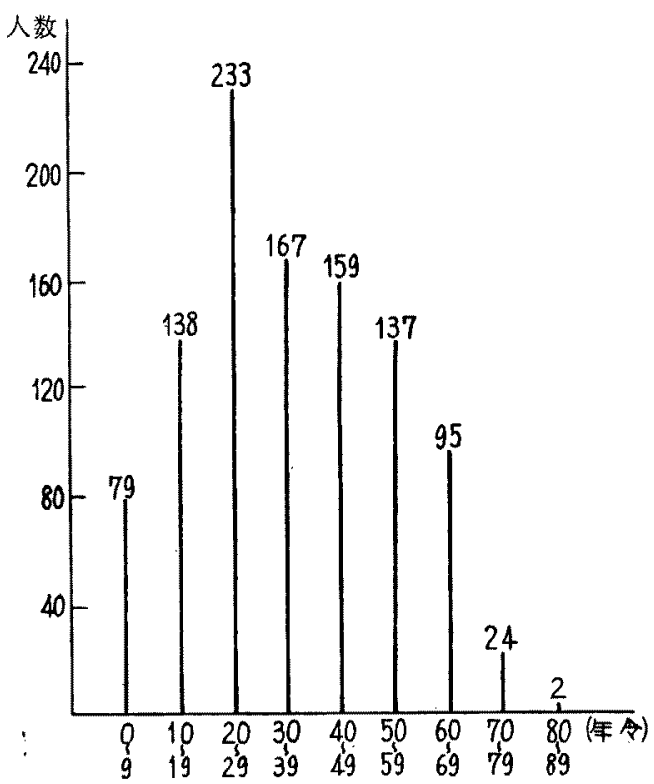

第 2 表 原因別分類

\begin{tabular}{|c|c|c|}
\hline & 例 数 & $(\%)$ \\
\hline メニエル氏病 & 154 & 14.5 \\
\hline 薬物中㳊 & 70 & 6.6 \\
\hline 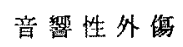 & 45 & 4.3 \\
\hline 遣伝 性 & 2 & 0.2 \\
\hline 先天性皿唨 & 46 & 4.4 \\
\hline 項部外第 & 41 & 3.9 \\
\hline 感染による & 88 & 8.3 \\
\hline そ の 他 & 4 & 0.4 \\
\hline 原因不明 & 608 & 57.4 \\
\hline 䚵 & 1058 & 100.0 \\
\hline
\end{tabular}

2. 原因別分類

原因別では原因不明 608 例で $57.4 \%$ を占め，最も多 ，原因の比較的確垫に判明した埸合は第 2 表の通りで ある、これらについては以下述べる，左右耳が原因の明 らかに翼なる病変を有する場合これを2例に数えた。

3. 原因と年令との開倸

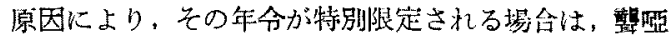
扰よび，ィ二エル氏病の場会であつて, 後者の場合は，

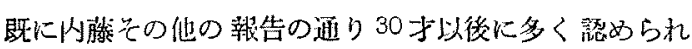

第 2 図 原因不明 608 例 年令別分類

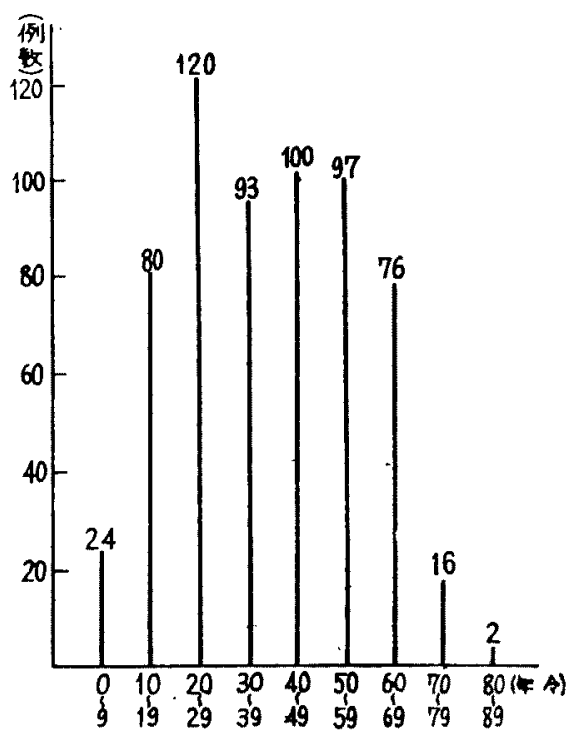

万(第3図).

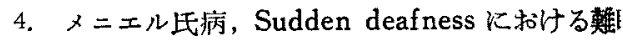
Кついて

154 例火訰いての峴察は第3図，第 3 表の通りで。 る.メニエル氏病に関して内藤の冁告に扎いて，両側 と考皇られる埸合は22\%であるが，我々の場合，奞

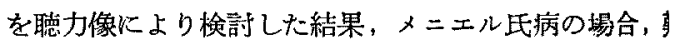
聴が雨側に存在する場合が高率に認められた。但し， 我ふは，難聴を伴小ぬ仮性メニエルと考它られる例は んでいない.

Sudden deafness についても，病变は片側性に突

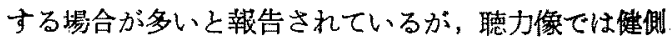
考克られる側にも，神経性難㯖の認められる場合が多? 認められた。たડ゙この埸合，難聴は 20〜30db 程度て 周波数も高音域に属し，自覚していない場合が多い，

第 3 図入ニエル病氏 137 例年令别分類

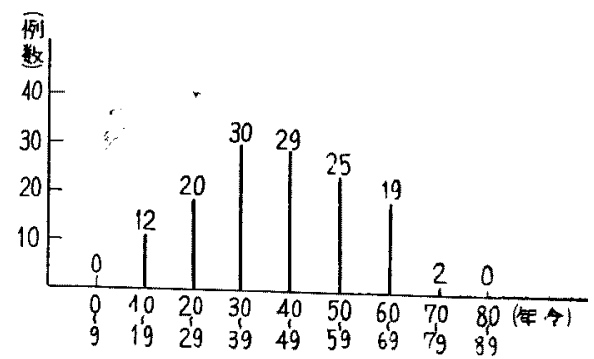


第3 痃 メニエル氏病（Sudden Deafness 老含を） 154 例の病僛，性別分類

\begin{tabular}{|c|c|c|c|c|c|}
\hline & \multicolumn{2}{|c|}{ メ $=$ ル氏病 } & \multicolumn{2}{|c|}{$\begin{array}{l}\text { Sudden } \\
\text { deaf ness }\end{array}$} & \multirow{2}{*}{ 計 } \\
\hline 性别 病側 & 両 僋 & 片 側 & 两 㑡 & 片 側 & \\
\hline 8 & 61 & 21 & 7 & 3 & 92 \\
\hline q & 29 & 26 & 4 & 3 & 62 \\
\hline 棓 & 90 & 47 & 11 & 6 & 154 \\
\hline
\end{tabular}

の点，突発性難聴が，必ずしも㔖発的に全く正常な聴力 耳より悪化する堨合のみでなく，ある程度の障害のある 内耳が何らかの原因で急激に悪化し，自覚される場合も 含まれるのでないかと考党られる。

5. 薬物中毒定例について

楽物中䓯により難聴をきたした70 例について，年令 別に分類すると，20才代，30才代に圧倒的に多く，半 数以上を占める(第 4 図).

0〜9才代の幼巟にる7名認めら礼る。この年代の慗 物感受性の高いことをしめしている、次に楽物を分類す ると，その内容は，SM 中書によるのが 64 名で $90 \%$ 以上をしめ，KM が3例でこれに続いている. その他 としては，サイクロセリン，テトリン，ネマトムル各1 名である(第 4 表).

6. 音望性外稘症例について

45 症例についての 年令別分類では 20 才代が圧倒的に

第 4 国

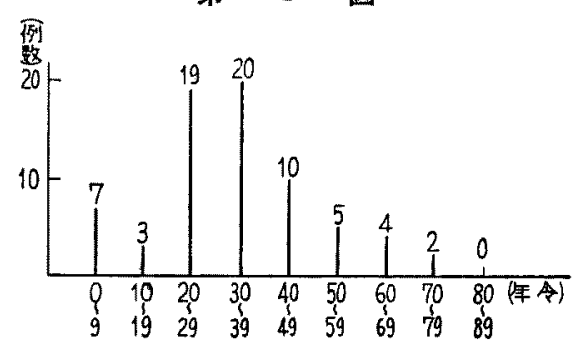

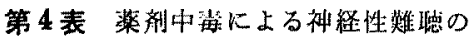
使用薬郕別分類

\begin{tabular}{|c|c|c|c|c|c|c|}
\hline & SM & $\mathrm{KM}$ & 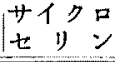 & $\mid$ テトリン| & $\begin{array}{l}\text { 市 } \\
ト\end{array}$ & 計 \\
\hline 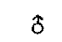 & 52 & 2 & 1 & 0 & 1 & 56 \\
\hline 웅 & 12 & 1 & 0 & 1 & 0 & 14 \\
\hline 苦 & 64 & 3 & 1 & 1 & 1 & 70 \\
\hline
\end{tabular}

多く，21 名で 50\% 近い值を示士（第 5 図）。

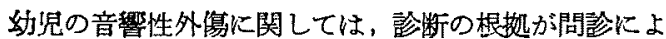
る店答にある故，不明である．男女別では男性に圧倒的 に多く，45 症例中 42 名である.これは騒音下に衝く場 合が男性に多いためであろうと推察される。なお，爆鳴 による，所謂，Detonation trauma 之思われる6例が 含弯れる（第 5 表）。

7. 感染による症例について

88 症例の年令別分類では第6图に和ける如く20才代 に最む多く，30名, 次いだ10才代, 次いで0〜9才代 である。

次に疾患別では慢性中耳炎に䍜患，以後渐次骨導德力

第 5 図

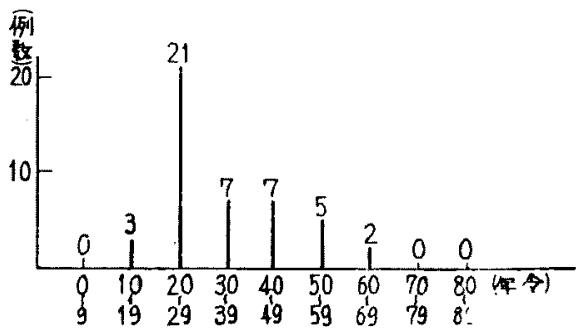

第 5 表 音踾性外稘の病侧分類

（）内は爆鳴によるもの

\begin{tabular}{|c|c|c|c|}
\hline & 片 側 & 両 侧 & 計 \\
\hline$\hat{\delta}$ & $3(2)$ & $39(3)$ & $42(5)$ \\
\hline 9 & $1(1)$ & $2(0)$ & $3(1)$ \\
\hline 萇 & $4(3)$ & $41(3)$ & $45(6)$ \\
\hline
\end{tabular}

第 6 网

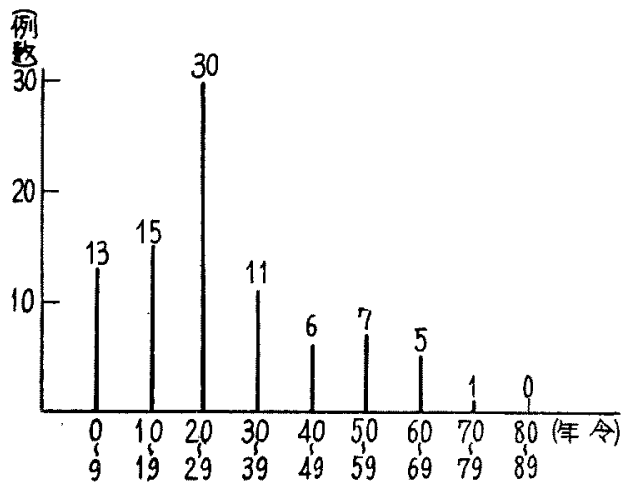


の低下をきたしたと思われる場合 48 例で一番多い，そ の中には急性中耳炎又は慢性中耳炎の急性增悪等に上り 経鼓室感染により内耳资を打こした場合も含音れる。

その他，病名の判明した埸合では，耳下腺炎に続く埸 合 5 例，麻抮 4 例，梅毒，チフス各 3 例である. 不明の 発熱知患が 20 列市るが，その中には，脳膜炎，肺炎等， 従来，内耳及びその聴覚中枢路を犯すと考えられる熱栍 疾患が疑われる例も含むが，不確実の答のため，不明 の発熱疾患汇含めた（第6表）.

第 6 表 感染による神释性難聴の原因別分類

\begin{tabular}{|c|c|c|c|c|c|c|c|c|c|}
\hline 側 & $\begin{array}{l}\text { 中 } \\
\text { 耳 } \\
\text { 焱 } \\
\text { 啳 }\end{array}$ & 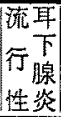 & $\begin{array}{l}\text { 麻 } \\
\text { 疮 }\end{array}$ & $\begin{array}{l}\text { 梅 } \\
\text { 毒 }\end{array}$ & $\begin{array}{l}\text { 䯣 } \\
\text { 膜 } \\
\text { 资 }\end{array}$ & $\begin{array}{l}f \\
7 \\
x\end{array}$ & 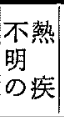 & $\begin{array}{l}z \\
D \\
\text { 他 }\end{array}$ & 計 \\
\hline 側 & 22 & 3 & 0 & 0 & 0 & 1 & 2 & 0 & 28 \\
\hline 両 側 & 26 & 2 & 4 & 3 & 1 & 2 & 18 & 2 & 58 \\
\hline 計 & 48 & 5 & 4 & 3 & I & 3 & 20 & 2 & 86 \\
\hline
\end{tabular}

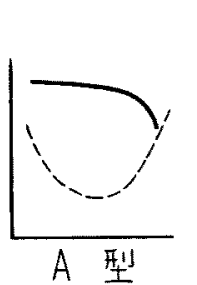

第 7 図

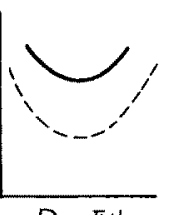

D 型
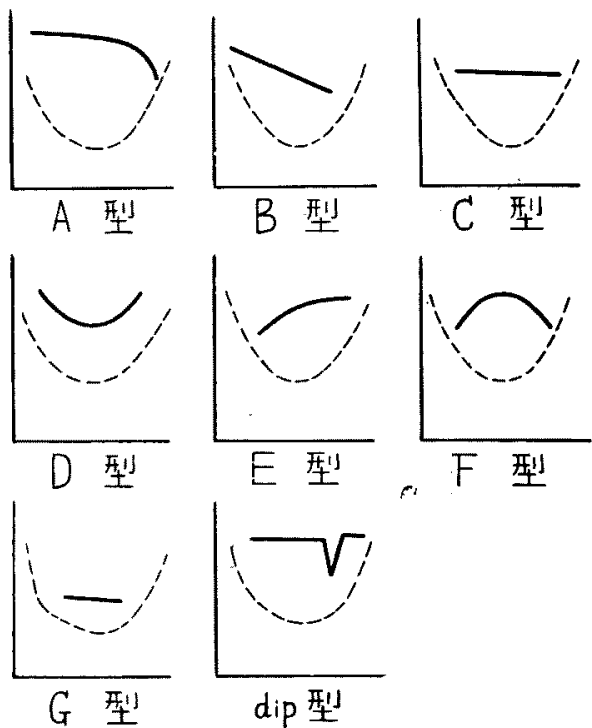

8. 原因不明の感音系難㯖について

757 耳（同一人で左右の聴力型に差を認好埸合二型 各々に加えた）。をその聴力型（東大，切替に上る分類 表)（第7図）に上り分類すると，B 型の高稠音漸傾型，

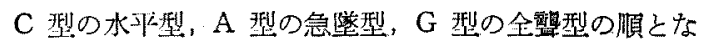
る. B，C，A 型が多いといら事は東大の 分類と比較し て耗型の比の差を除いては，大略同じである (符8表).
第 8 表 原因不明感音采難聴の聴力分類型

\begin{tabular}{|c|c|c|c|c|c|c|}
\hline & & & $\delta$ & 유 & 詰 & $\begin{array}{cc}\text { 東 } \\
\text { (昭22 } \\
\text { 太 } 24)\end{array}$ \\
\hline A & & 型 & 63 & 51 & 114 & 14 \\
\hline B & & 型 & 152 & 68 & 220 & 19 \\
\hline $\mathrm{C}$ & & 型 & 89 & 61 & 150 & 26 \\
\hline D & & 琹 & 33 & 25 & 58 & 8 \\
\hline$E$ & & 型 & 19 & 13 & 32 & -2 \\
\hline $\mathbf{F}$ & & 型 & 30 & 11 & 41 & 2 \\
\hline G & & 型 & 51 & 37 & 88 & 21 \\
\hline $\operatorname{dip}$ & & 型 & 15 & 3 & 18 & \\
\hline$y$ & , & 他 & 23 & 13 & 36 & \\
\hline & 計 & & 475 & 282 & 757 & $92 i$ \\
\hline
\end{tabular}

第 8 図
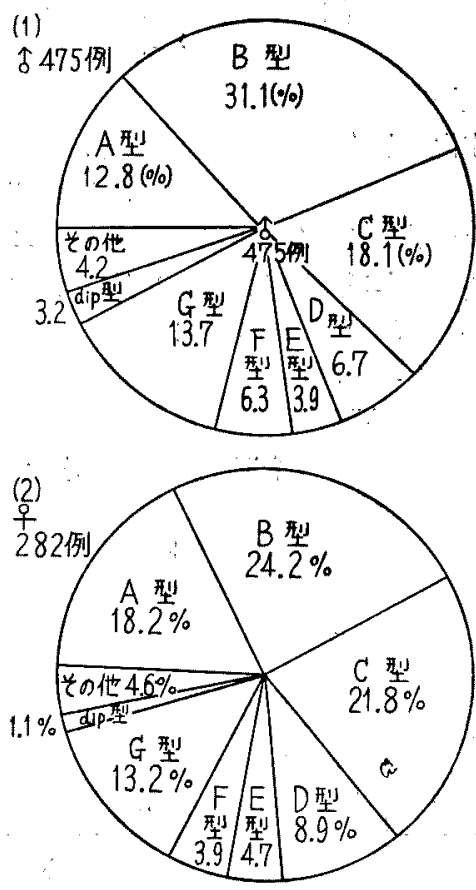

3. 総括および考按

感音系難聴は耳䍙科領域の大きい問題であり，その原 因，治療上も今後大いに研究すべき課題である，その原 因に関しては前述の如く不明の場合が多く，その場合の 原因として循環障害説, ウイルス説, アレルギー説, 及 び Sercer の内耳道の化骨現象による螖牛神経王迫説等 仮説が多くあるが，いずれも単独で多くの原因不明の感 音系難聴を眖明し得ない，原因不明例の聴力型分類より 
洘察すれば多くが渐次聴力の悪化索さたす傾向のもので あり，又耳鳴，䁙最を伴らことも少いため病変の早期発 見を困難ならしめている。

ま大㔖発性難㯖の場合でる我々の統計では反対側にも 高音域の軽度の感音系難聴を認める例が多いことからる 突発性顛聴といえどるとの発病前比無自覚性の軽度の感 音系難聴が存在した埸合がかなりあるのではないかと推 察する。

感音系難聴の発病過程として考只られる場合は (1)組織の退行变性为長期間汇互つて進展持緢し, 不可 逆性病変江向与場合.

(2)可逆性の病変があり，去れが急激に高度に悪化して 不可逆性の病変となる場合，及び

f(3)全く正常な組織が急激に悪化する場合，

以上 3 少の境合が考えられるが，前 2 者の比率がが 的大きいと考它ら机る。

従つて組織が不可逆性となつて後あるいは陳旧化して 後、治療を行ら場合が多くこ〉に绫疾患の治療成績の低 い理由がある，現在のところ，病変が可逆性であるかど らか活，病歴，聴力像等を参考として，かなり長期の根 気のいる治潦を試み，その結果でなけ放ば決定できな

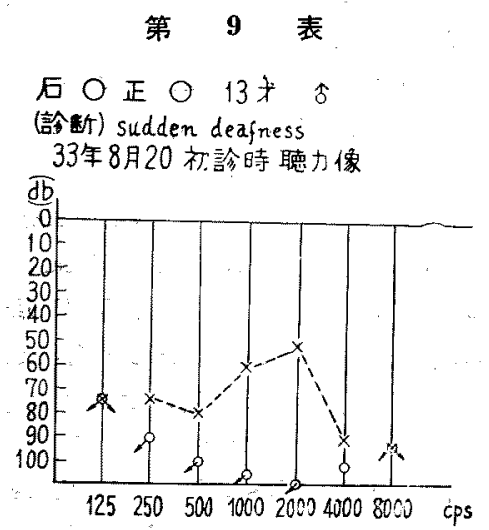

イイロン $50 \mathrm{cc}$ V.B. $100 \mathrm{mg}$ 各々20本 ヒロカルピン 1 Kur 40日間３3年9月 24 日愳力像

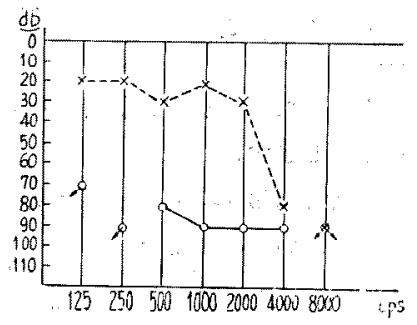

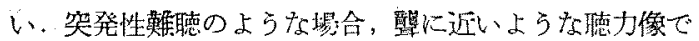

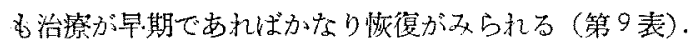
現在迄火行な和机てきた治虏法之してはV.B 1 高単 位静注淹法, メイロン $250 \mathrm{cc}$ 点滴療法, アリナミン内 服又は静注漈法, V.B B $_{1}$ パンピング祭法, ピロカルピン 璙法，低周波潦法、チオクタン墔注、コンドロイチン硫

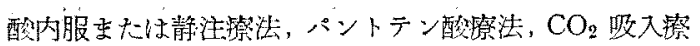
法（九大) 等がある.

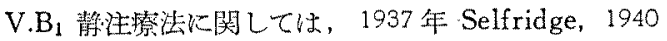
年河出，1943 年 Guggenhein, 1951年切替, 1953 年吉 田等多数の報告があり，我々も現在，㕍々使用している が，談薬剤の作用は，衆知の如く，燐酸エステルが Co-

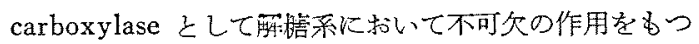
他，生体内の酸化邉元機構に関与し，焦性ブドウ酸から 脂肪酸の合成, 更飞 acetylcholine の分酳醇素の作用学 抑淛し，また腸組織に执いて焦性ブドウ酸から acetylcholine の合成される埸合に特殊な関捙があることが知 られている.

V. $\mathrm{B}_{1}$ 筝注療法, むたは pumping 療法を含めて内耳 組繊の如き終末動脈によりその栄亘が支配されている組 織の病変に対する治療は, 薬滆の投与方法に難しい問題

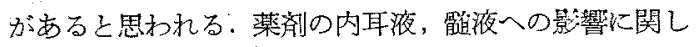
ては後藤（修）等の動物実験による派告すあるが，かな り長期化たり形成さ机る病变が考完ら机る原因不明の

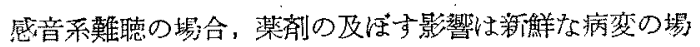
合と相当異ると思われる。

そ犺は，動㟲硬化に対する実験，治療の埸合等上相通 じるすのがあると考克られる。

一時, pumping 療法が学会誌派々みられだが，そ

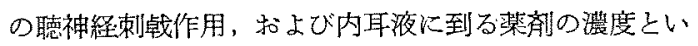
う面上り，有効乞いわれるか゚，去の作用機序は必ずしも 全面的に是認されていないし，またとの效果も限界が認 められる・ピロカルピン䉘法は, 古くから用いられてお

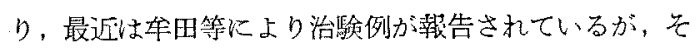
の choline 作働性神経と作用して，その末枮興舊をき たす作用はかなり有効之思われる。

まだ，最近用いられてきだンドロイチン硫酸搃し ては河田等の啹告もあり，その作用機序として侵翼に対

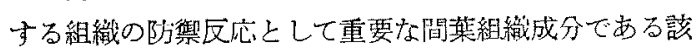

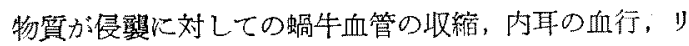
ンパ流動障害を故善するといわれている。

その治療成績の報告は必ずしもV.B 1 静注療法より勝 つているとは思われない。 
我々の教室にては，以前より， $7 \% \mathrm{NaHCO}_{3}$ 静注療 法を試みており，かなり有効であることを知つた，該蒋 物の作用機序は，終末動脈発症した末梢血管障害の寛 解にあり， $\mathrm{CO}_{2}$ による末梢血管脑張作用执よび炎症性 浮腫に対する高張液としての物理的作用, 更に上述のコ ンドロイチン硫酸，へパリン等酸性粘液多結類の重合， 透過性に対する組織 $\mathrm{pH}$ の影輩といら大島等の 報告に みられるような間葉組織の病的变化の正常化汇関倸があ ると考えられる。

更に，パソトテン酸，チオクタン等る用いられている が，前者は神縃炎に有効である生体内微量活性物質であ り, 後者は肝障害および, 慢性炎症，組織の修復に有効 であるといるれる。

その他，低周波潦法，ATP 製剮等種々なる治潦法が 行われているのか現情である.いづれの薬郕, 治潦法も 感音采晎聴の原因を考克るとき，単独で万全とは考克 難い。

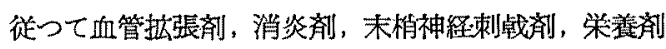

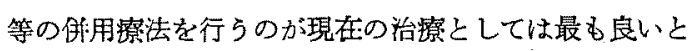
思われる。

\section{4. 結語}

(1) 昭和 33 年度阪大病院耳鼻科外整患者の中, 感音 系難聴之考兄られる患者 1034 名の統計的観察を行つた．

（2）年令別ては 20 才代に最む多いが，各年代にわた つてかなり広い分布を示し，性別では男性に多い。

（3）原因別では原因の不明な場合が多く，先の場合の 聴力型は, 高稩音渐傾型, 水平型, 急型型が多い,

（4）メニエル氏病, 突発性難聴で聴力像では泪側の 感音系難聴を示した症例が多い。

（5）音㟙性外傷は，圧倒的に男性に多い。

\section{参考文献}

1) Lederer, F.L.: Handbuch d. H.N.O. hk. (Denker. Bd. VI, 1926.

2) 日本耳鼻咽喉科全書, 第 1 巻, 呫器, 第 3 冊臨床編, 各論 I, 291 349. 3) 白 井：一ノポシ油汇よる難㯖の1 例，耳門咽喉科，21，2， 2, 昭 24.4 4) 切替一郎他：感音系難㯖飞関する臨床 的研究，日耳鬼，53巻，11号，377，昭25.5) 執行

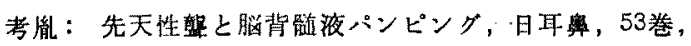
$3,93 \sim 103$, 昭和 $25.5,159 \sim 165$, 昭 25.6 ). 宮崎 暸：パンピングが効を奏せし外第性難聴の 1 例，日耳 鼻，53 巻，3，109，昭 25.7$)$ 木村円治：内耳炎の統 計的镜察，日耳算 $53 ， 3 ， 109$ ，昭 25，8）坂本：䃽 性難聴を起した四塩化エチレン中雷例，讋と治，38，8，
昭 25.9）後膦修二他：内耳液と噵液の関係，耳咽

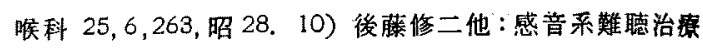
の本熊，耳蕃咽喉科，25，7，311，昭 28.11）吉田祺一郎

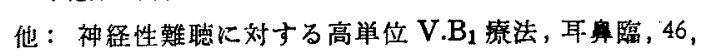
$10 ， 740$ ，昭 $28.12 ）$ 長谷川高敏：末梢循環障害上 重曹注射，臨床之研究，37巻，6号，昭 35：13）青 木一郎他：原因不明の慢性進行性難聴飞対する鲔液内

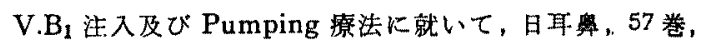
4, 335 344, 昭 29. 14）山川強四郎：老人性難㯖の

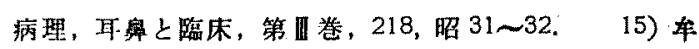

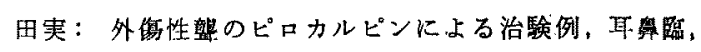
49, 3, 昭 31. 16) 佐藤武男他：Sudden deafness にっいて, 耳·鼻臨，50, 8, 75̣3, 昭 32.17 ) 志多亭: Dihydrostreptomycin の蝸牛障害並びK Condroitin sulpxate の該障害に対する 予防的効果に関する実臨的 研究，日耳奥， 60 巻， 2 号, 昭 32 . 18) 小林, 恒久: 老人性難聴に関寸る研究，日耳鬼，61巻，1，56，昭33.

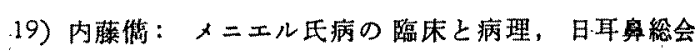
（第60回）宿題報告，昭 34.20 ）河田政一他：神経 性難聴、メニエル氏病に対する ATP-Na 使用経験, 耳 鼻臨, 30 巻, 12 号, 997〜1002, 昭 33. 21) 河村進 市：コンドロン長期投与による職業性難聴進行防止効 果について, 耳舆臨; 31 巻, 8号, 597〜601, 昭 34. 22) 中村四郎他: Sudden deafness の臨床的観察, 耳 鼻臨, 31 巻, 5 号, $327 \sim 338$, 昭 34.23 ) 谷口武彦 他：外来患者の重曹水静注療法の現況，耳蹦，52巻， 4, 439 444, 昭 34. 24) H.L. Wullstein: Endoly. $\mathrm{mph}$ and Perilymph in Ménière's Disease (Archiv. of O.R.L. 73. 3. 11. 61). 25) S.D. Erulkar: Carbonic anhydrase and the inner ear (Nature. 189, 4763, '61). 26) 大島良雄他：結合識病変をめぐる 諸問題，最新医学，16,7, 昭 36.27$)$ 後藤敏郎他： 耳鼻咽㮢科学, 上巻, 458 588, 28) Sercer: Über die Ursache der progressiven Altersschwerhorigkeit (Acta. of O.R.L. Suppl. 143). 29) 切替一郎他:

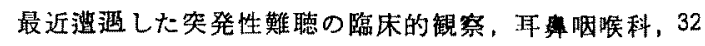
巻, 3号, 177 184, 昭 35 .

稿を終るにあたり，恩師長谷川高解教授の御 校閱を感謝致します

本諭文の要旨は第 100 回日本耳咽喉科学会 大阪地方会において発表した。

（原稿到着 =昭和 36.9.4 日） 